\title{
Seed Morphology of Some Species in the Family Gentianaceae
}

\author{
Tatyana Nikolaevna Kataeva, Alexey Sergeevich Prokopyev*, \\ Alyona Aleksandrovna Akinina and Olga Dmitrievna Chernova
}

\author{
National Research Tomsk State University, Siberian Botanical Garden, \\ 36 Lenin Prospekt, Tomsk, 634050, Russia.
}

DOI: http://dx.doi.org/10.13005/bbra/1902

(Received: 10 October 2015; accepted: 21 November 2015)

\begin{abstract}
In this work, we investigated the outer and inner morphological characters of the seeds of 13 species in the family Gentianaceae. We also identified the main morphometric parameters and described the shape, coloration and sculpture of the seed surface. Some aspects of their internal structure were analyzed as well.
\end{abstract}

Key words: Gentianaceae, seeds, morphology, surface sculpture.

Gentianaceae Juss. is a large family of flowering plants, which is widely spread in the modern biota and comes from the ancient times. Its numerous representatives are spread throughout all the continents (except for the Antarctic) and occur on a wide environmental range: tundra, steppes, forests of different types and latitudes, meadows and marshes. The pattern of the Gentianaceae geographical range suggests that the family dates a long way back. In the modern geological era, it has a vast disjunctive areal, which could only have formed over a long time. The family currently numbers about 80 genera and over 1,000 species predominantly growing in mountain areas of the northern hemisphere. The life forms of Gentianaceae are very diverse and depend on their inhabitation. In the mid-latitudes and mountains, annual and perennial grasses prevail, whereas in the subtropical and tropical areas you can also find shrubs, sub-shrubs, lianas and small trees ${ }^{1,2}$.

\footnotetext{
* To whom all correspondence should be addressed. E-mail: rareplants@list.ru
}

The representatives of family Gentianaceae are of great practical importance in human life. Many of these are known for their ornamental properties and are used to design rock gardens $^{3-5}$. Some species are nectariferous, forage and dye plants ${ }^{6,1}$. However, their major economic application comes from their value as medicinal plants ${ }^{7}$. Species of the family Gentianaceae are widely used in Tibetan traditional medicine ${ }^{8,9}$.

The taxonomy of the family is very complex. Most contradictions and arguments among researchers are related to the classification of the genus Gentiana L., the largest and most significant one in the family. Despite the abundance of research on the taxonomy of the genus and family in general ${ }^{10-14}$, scientists have not yet agreed on the rank (section or genus) for the taxa united under the common name of Gentiana s.l. Nomenclature combinations within the family Gentianaceae are not only based on the traditional morphogeographical research method, but also involve anatomical, karyological, biochemical, cytological and other advanced methods.

When dealing with debatable issues of Gentianaceae systematics, scientists pay 
increasingly more attention to the studies of seed and fruit morphology $y^{15-17}$. Among the characters of seed morphology, of special interest is the seed coat (exotesta) sculpture. According to Barthlott's data $^{18}$, the seed coat characters are stable, conservative, and almost unaffected by the environment, hence high taxonomic value. Carpological studies are highly significant for not only taxonomy but also seed identification. Seed descriptions can be used to add to the diagnoses of species in floras and to compile keys to plants based on carpological data. Therefore, a morphological analysis of the representatives of family Gentianaceae has a certain value and can be used to diagnose species.

The aim of this work is to study the morphological characters of seeds and seed coat surface in 13 species of the family Gentianaceae.

\section{Objects and methods}

We used the seeds collected from native and introduced plants on the territory of the Republic of Altai and Tomsk Region (Russia) as test materials. We chose the following 13 species cultured in Siberian Botanical Garden of Tomsk State University as objects of our study: Gentiana acaulis L., G. asclepiadea L., G. cruciata L., G. lagodechiana (Kusn.) Grossh., G. lutea L., G. macrophylla Pall., G. paradoxa Albov, G. pneumonanthe L., G. septemfida Pall., G. tibetica King ex Hook. f., G. grandiflora Laxm., G. uniflora Georgi, Centaurium erythrea Rafn. The names of the species are given as they appear on The Plant List except for $G$. lagodechiana, which this database lists as a synonym of G. septemfida. However, Russian taxonomists ${ }^{12}$ describe this species as a separate one, endemic to the Caucasus. In this article, we also adopt this viewpoint.

The morphological characters of seeds (size, shape, and color) were studied under an MSP1 stereo microscope (Lomo, Russia) at a $30 \times$ and $40 \times$ magnification. The sculpture of a seed surface was observed with a Philips SEM 515 Scanning Electron Miscroscope (the Netherlands) at $30 \times$ to $600 \times$ magnification. The weight of 1,000 seeds was measured on a DX-200 electronic scale (A\&D, Japan) graduated in $0.001 \mathrm{~g}$.

The morphological characters of seeds were described in line with the research by Z.T. Artyushenko ${ }^{19}$ and T.A. Fedotova ${ }^{20}$. When describing the sculpture of a seed surface, we used the classification and terminology from the research by W. Barthlott ${ }^{18}$ and T.I. Kravtsova ${ }^{21}$. We took into account the following characters: shape of exotesta cells, pattern of the anticlinal walls (thickness and curvature) as well as the relief of the outer and inner periclinal walls.

The seed cross sections were prepared on an MZ-2 freezing microtome (Tochmedpribor, Ukraine). The seed anatomy was assessed under an Axio Lab A1 light microscope (Carl Zeiss, Germany) at 50× and 100× magnification. The images were processed and analyzed by means of Axio Vision software.

\section{RESULTSAND DISCUSSION}

Seeds of the representatives of Gentianaceae are numerous, mostly small or very small in size. By shape, they can be circular, broad ovate, oblong, elongated or fusiform. There are also winged seeds. The seed coat surface of most species is well-sculptured and rather diverse; it may be reticulate, rugose or colliculate ${ }^{20}$.

Following Barthlott ${ }^{18}$, we differentiate between the primary and secondary structure of a seed coat surface. The primary sculpture is determined by the shape of exotestal cells. In Gentianaceae exotestal cells, it is mostly the anticlinal and inner periclinal walls that become thicker, whereas the outer periclinal wall remains thin. Thin outer periclinal walls go down into the cellular cavity, whereas the thickened anticlinal walls appear to be raised and fixate the cell outlines, thus defining the reticulate character of the seed surface $^{20}$. Thus, what lies behind the primary surface sculpture of the seeds in the species under study is the reticulate type of surface. The secondary sculpture is mainly defined by the cuticular microrelief of the outer periclinal wall ${ }^{18}$. However, the outer periclinal walls of Gentianaceae are often degraded, the thickenings of anticlinal and inner periclinal walls become visible. We can view these as the secondary sculpture. Therefore, when describing the surface of a seed coat, we relied on the previously developed approaches with due consideration of our own additions.

\section{Morphological characteristics of seeds}

Gentiana uniflora. The seeds are oval, dark brown, 0.98 (0.85-1.10) $\mathrm{mm}$ long and 0.47 (0.43$0.55) \mathrm{mm}$ wide. One thousand seeds weigh $0.066 \mathrm{~g}$. 

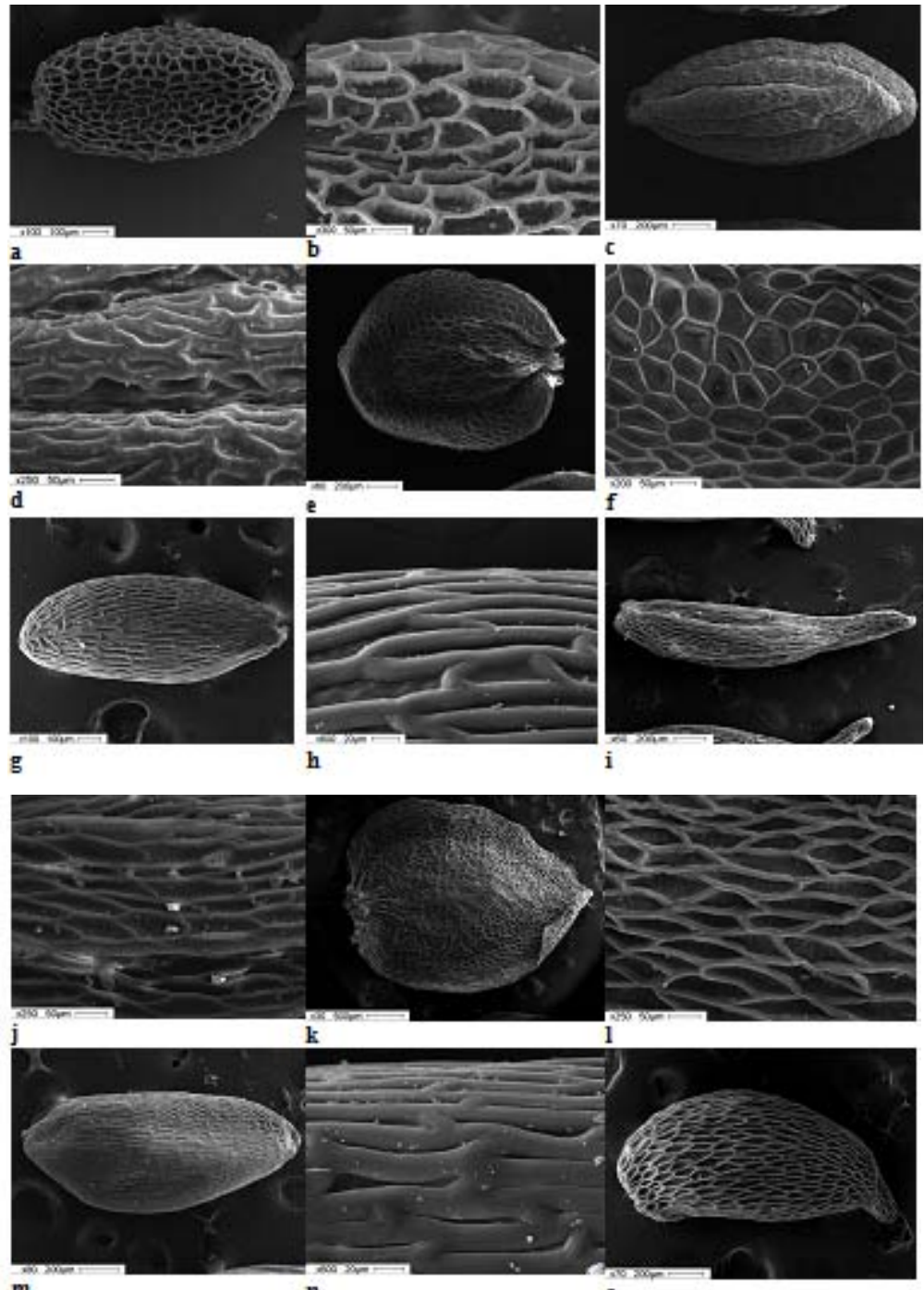

m
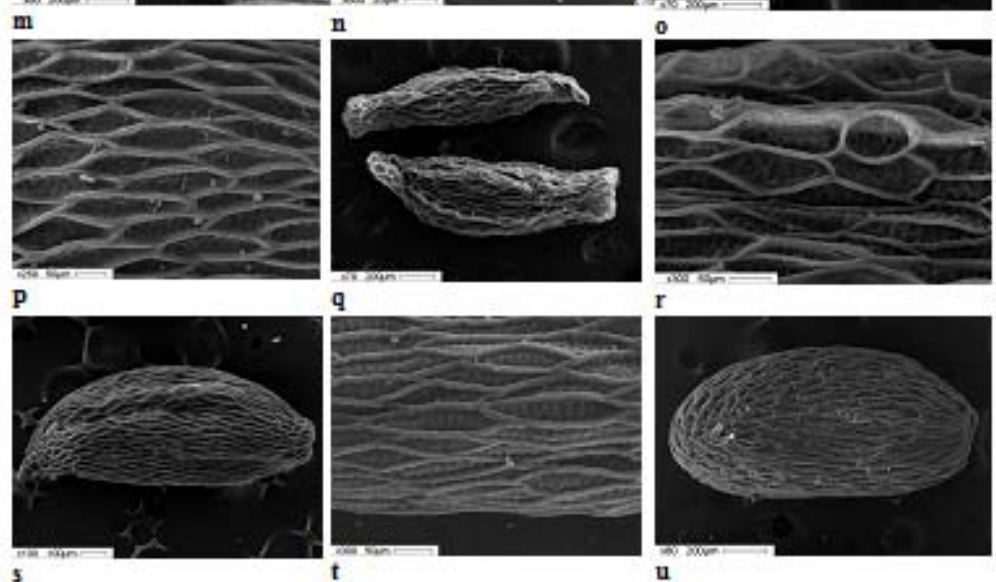

u

Fig. 1. Ultrasculpture of Gentianaceae seed surface: Gentiana uniflora (a, b); G. acaulis (c, d); G. asclepiadea (e, f); G. cruciata (g, h); G. lagodechiana (i, j); G. lutea (k, l), G. macrophylla (m, n); G. paradoxa (o, p); G. pneumonanthe (q, r); G. septemfida (s, t); G. tibetica (u, v); G. grandiflora (w, x), Centaurium erythraea $(\mathrm{y}, \mathrm{z})$ 
The surface sculpture is reticulate; the exotestal cells are isodiametric and tetra- or pentagonal. The anticlinal walls are raised, thin, with straight boundaries. Outer periclinal walls are concave, thin, partly degraded; the inner surface of cells is transversely costate (Fig. 1 a, b).

G. acaulis. The seeds are oblong elliptic, light brown, with irregular ribs, $1.59(1.40-1.83) \mathrm{mm}$ long and 0.85 (0.75-0.93) mm wide. One thousand seeds weigh $0.467 \mathrm{~g}$. In cross-section, they are circular and with deep striates. The surface sculpture is reticulate-undulate; the cells are oblong, anticlinal walls are raised, thickened, slightly curved. The secondary sculpture of the seed coat surface is not pronounced (Fig. $1 \mathrm{c}, \mathrm{d}$ ).

G. asclepiadea. Seeds are circular, flattened, light yellow-brown, winged, 1.76 (1.502.13) $\mathrm{mm}$ long, 1.39 (1.0-1.75) mm wide, and 0.42 $\mathrm{mm}$ thick. Without wings, the seed is ovate, 1.25 (1.03-1.58) $\mathrm{mm}$ long and 0.70 (0.45-1.45) mm wide. One thousand seeds weigh $0.143 \mathrm{~g}$. The wings are $0.34 \mathrm{~mm}$ wide, located along the circular length of the seed and only discontinue near the raphe. The surface sculpture is reticulate; the cells are large and of different shapes depending on their location on the seed: oblong on the seed body; the winged cells are isodiametric and pentagonal. The anticlinal walls are raised, thin, with straight boundaries. Outer periclinal walls are thin, concave, sometimes with a circular opening in the center formed because of its partial degradation. Inner

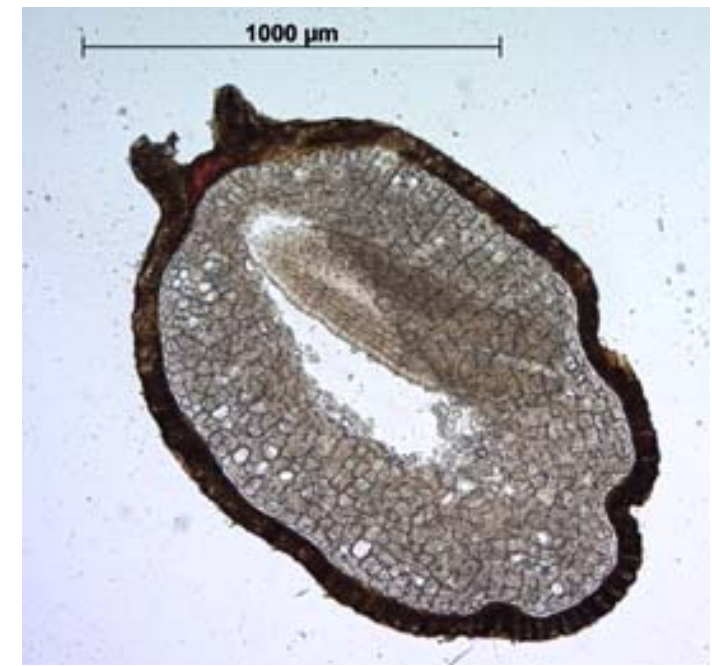

(a) periclinal walls have a finely reticulate sculpture (Fig. 1 e, f).

G. cruciata. Seeds are oblong elliptic, brown, 1.20 (1.03-1.40) mm long and 0.53 (0.48-0.58) $\mathrm{mm}$ wide. One thousand seeds weigh $0.193 \mathrm{~g}$. The surface sculpture is reticulate-undulate; the cells are narrowly oblong. The anticlinal walls are raised, thickened, with straight boundaries. The secondary sculpture is not pronounced (Fig. $1 \mathrm{~g}, \mathrm{~h}$ ).

G. lagodechiana. The seeds are oblong, elongated, light brown, 1.47 (1.30-1.73) mm long, 0.47 (0.40-0.50) mm wide, attenuatous. One thousand seeds weigh $0.057 \mathrm{~g}$. The surface sculpture is oblong-reticulate; the cells are elongated, penta- or hexagonal. The anticlinal walls are raised, thin, with straight boundaries. The outer periclinal walls are thin, partly degrading. The surface of cells is fine-reticular (Fig. $1 \mathrm{i}, \mathrm{j}$ ).

G. lutea. The seeds are circular, flattened, brown, winged, 3.26 (2.40-3.57) mm long, 2.60 (2.332.93) $\mathrm{mm}$ wide, and $0.5 \mathrm{~mm}$ thick. The wingless seed is ovate, 2.60 (2.27-2.93) $\mathrm{mm}$ long and 1.88 (1.43-2.17) mm wide. One thousand seeds weigh $1.010 \mathrm{~g}$. The wing surrounds the seed fully and only discontinues near the raphe. The wing is up to $0.5 \mathrm{~mm}$ wide. The surface sculpture is reticulate; the cells are slightly elongated, pentagonal or diamond-shaped, more oblong on the seed body. The anticlinal walls are raised, thin, with straight boundaries. The pit surface is transversely ribbed (Fig. 1 k, l).

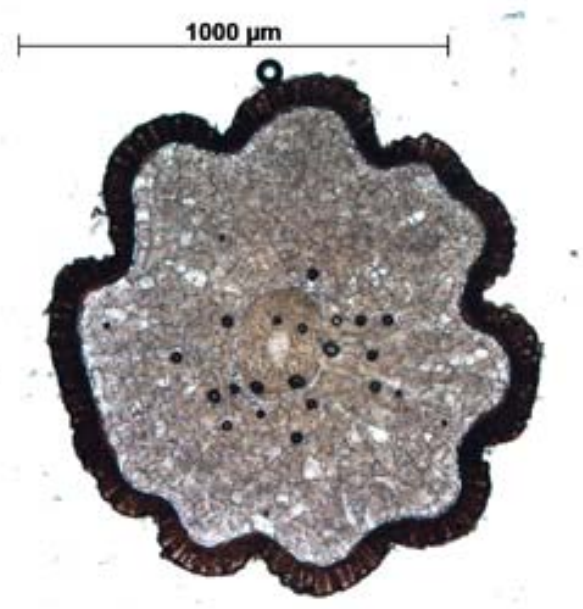

(b)

Fig. 2. G. acaulis seed section: longitudinal (a) and transverse (b) 
G. macrophylla. The seeds are oblong elliptic or obovate, brown, 1.33 (1.18-1.43) mm long and $0.63(0.55-0.75) \mathrm{mm}$ wide. One thousand seeds weigh $0.257 \mathrm{~g}$. The surface sculpture is reticulateundulate; the cells are narrow oblong, anticlinal walls are raised, thickened, with straight boundaries. The secondary sculpture is not pronounced (Fig. $\mathrm{m}, \mathrm{n}$ ).

G. paradoxa. The seeds are obovate, slightly falciform, brown, 1.61 (1.30-1.75) mm long and $0.70(0.55-0.75) \mathrm{mm}$ wide, pointed. One thousand seeds weigh $0.283 \mathrm{~g}$. The surface sculpture is reticulate; the cells are elongated diamond-shaped. The anticlinal walls are raised, thin, with straight boundaries. The outer periclinal walls are thing, partly degraded. The pit surface is finely reticulate (Fig. 10 , p).

G. pneumonanthe. The seeds are oblong fusiform, brown, 1.39 (1.13-1.60) $\mathrm{mm}$ long and 0.44 (0.38-0.50) mm wide. One thousand seeds weigh $0.043 \mathrm{~g}$. The surface sculpture is reticulate; the cells are large, isodiametrically polygonal or oblong. The anticlinal walls are raised, thin, with straight boundaries. The outer periclinal walls are thin, concave, partly degraded. The pit surface is finely reticulate (Fig. 1 q, r).

G. septemfida. The seeds are oblong, slightly fusiform, light brown, $1.48(1.25-1.73) \mathrm{mm}$ long and 0.51 (0.43-0.70) mm wide, obtusely pointed. One thousand seeds weigh $0.147 \mathrm{~g}$. The surface sculpture is oblong-reticulate; the cells are elongated and polygonal. The anticlinal walls are raised, thin, with straight boundaries. The outer periclinal walls are thin, partly degraded. The pit surface is finely reticulate (Fig. $1 \mathrm{~s}, \mathrm{t}$ ).

G. tibetica. The seeds are elliptic, brown, 1.44 (1.08-1.73) $\mathrm{mm}$ long and $0.67(0.53-0.80) \mathrm{mm}$ wide. One thousand seeds weigh $0.400 \mathrm{~g}$. The surface sculpture is reticulate undulate; the cells are narrowly oblong. The anticlinal walls are raised, thickened, and curved. The secondary sculpture is not pronounced (Fig. $1 \mathrm{u}, \mathrm{v}$ ).

G. grandiflora. The seeds are oblong elliptic, light brown, $1.08(0.80-1.25) \mathrm{mm}$ long and $0.58(0.50-0.68) \mathrm{mm}$ wide. One thousand seeds weigh $0.160 \mathrm{~g}$. The surface sculpture is reticulate; the cells are large, isodiametrically polygonal or slightly extended. The anticlinal walls are raised, thin, with straight boundaries. The outer periclinal walls are sunken, thin, mostly degraded. The pit surface is finely reticulate (Fig. $10, \mathrm{p}$ ).

Centaurium erythraea. The seeds are circular, angular, brown, $0.33(0.25-0.40) \mathrm{mm}$ long and $0.28(0.25-0.33) \mathrm{mm}$ wide. One thousand seeds weigh $0.013 \mathrm{~g}$. The surface sculpture is reticulate; the cells are large, isodiametric, and penta- or hexagonal. The anticlinal walls are raised, thickened, and curved. The outer periclinal walls are somewhat concave. The pit surface is finecolliculate (Fig. 1 y, z).

The analysis of the data obtained has shown that the morphological characters of the seed surface in the species under study are defined by the shape of exotestal cells, the thickness and curvature of their anticlinal walls as well as the relief of the periclinal wall surface. The primary surface sculpture of G. uniflora, G. asclepiadea, G. pneumonanthe and $G$. grandiflora comprises isodiametric cells with raised thin anticlinal walls. Exotestal cells of the seed coats of G. cruciata and G. macrophylla are elongated, narrow, with straight thickened anticlinal walls. The thickened anticlinal walls of the G. acaulis and G. tibetica cells are notable for their curvature. The secondary sculpture of a seed surface is largely defined by the relief of the inner surface of the cells. It can be corrugate (G. uniflora, G. lutea), finely reticulate (G. paradoxa, G. pneumonanthe, etc.). When the outer periclinal wall remains intact, the secondary sculpture is not readily visible, except for $C$. erythraea, in which the reticulate seed surface is superimposed by the colliculate microrelief of the outer periclinal wall. In the species with thickened and approximate anticlinal walls, the secondary sculpture is not pronounced either (G. acaulis, $G$. cruciata, G. macrophylla, G. tibetica).

As it follows from the literature ${ }^{20}$, the inner morphology of the seeds of the species under study is uniform. Our studies of G. acaulis seeds helped us establish that the seed coat is thin, firmly against the endosperm and its thickness is $67 \mu \mathrm{m}$. The endosperm is $299 \mu \mathrm{m}$ thick and well developed, with several cellular layers. It is located peripherally. The embryo is inferior to the endosperm in terms of volume, but it is quite large and its parts - cotyledons, hypocotyl and radicle - are well differentiated. It is straight, elongated, $840 \mu \mathrm{m}$ long and $235 \mu \mathrm{m}$ wide, attached to the axis 
and located closer to the micropylar part of the seed (Fig. 2). The area of the embryo is $0.165 \mathrm{~mm}^{2}$, which makes for $23.7 \%$ of the area of the endosperm.

\section{CONCLUSION}

The seeds of the species of family Gentianaceae under study are numerous, small, diverse in shape and size, 0.33 to $3.26 \mathrm{~mm}$ long and 0.28 to $2.60 \mathrm{~mm}$ wide. The smallest and lightest seeds were found in Centaurium erythraea $(0.025$ $\mathrm{g} / 1,000 \mathrm{pcs})$ and the biggest and heaviest ones, in Gentiana lutea $(0.133 \mathrm{~g} / 1,000 \mathrm{pcs})$. The seed shape varies from circular to fusiform. Most studied species have elongated seeds. The seeds of $G$. lutea and G. asclepiadea are flattened and winged. The seeds are brown-colored with a gradient from light yellow-brown to dark brown tones. The raphe is well defined, rounded, sunken and located at the end of a seed. Depending on the shape of the exotestal cells and the pattern of the anticlinal walls, we differentiate between three types of the primary sculpture of a seed surface: reticulate, elongated reticulate, and reticulate undulate. Most studied species have a pronounced secondary sculpture defined by the relief of the exotestal cell surface, which can be colliculate, transversely ribbed, and finely reticulate.

The internal morphology of G. acaulis seeds is notable for a well developed endosperm that surrounds the embryo. The embryo is attached to the axis and its parts - cotyledons, hypocotyl and radicle - are well differentiated. The area of the embryo is less than $25 \%$ of that of the endosperm.

\section{ACKNOWLEDGMENTS}

This work was supported by the Ministry of Education and Science of the Russian Federation (\#1149).

\section{REFERENCES}

1. Pisyaukova, V.V. Familia Gentianaceae. In: Life of Plants, 1981; 5(2): 365-370.

2. Takhtajan, A.L. Diversity and classification of flowering plants. New York, Columbia University Press, 1997.

3. Markovskiy, Yu. B. Alpine gardens and rock gardens, Moscow, 2011.

4. Wilford, R. Alpines from Mountain to Garden. UK: Royal Botanic Gardens, Kew, 2010.

5. Diev, M.M. Great encyclopedia of perennial flowers, Moscow, 2011.

6. Useful plants of West Siberia and prospects of their introduction / Editor-in-Chief K.A. Sobolevskaya. Novosibirsk, 1972.

7. Plant resources of Russia: Wild-growing flowering plants, their composition and biological activity. Vol. 4. Family Caprifoliaceae - Lobeliaceae / Editor-in-Chief A.L. Budantsev. Saint Petersburg, Moscow, 2011.

8. Aseeva, T.A., Blinova, K.F., Yakovlev, G.P. Remedial plants of Tibetan medicine. Novosibirsk, 1985.

9. Bazaron, E.G., Batorova, S.M. Tibetan recipes in traditional Mongol medicine (based on materials of Ontsar Gadon treatise). Ulan-Ude 2002.

10. Kuznetsov, N.I. Subgenus Eugentiana Kusnez. of the genus Gentiana Tounfort. Taxonomical, morphological and geographical processing. In: Proceedings of the St. Petersburg Society of Natural History, 1894.

11. Holub, J. New Names in Phanerogamae 2. In: Folia Globot. Phytotax. Praha, 1973; 8(2): 821829.

12. Grossheim, A.A. Gentianaceae. In: USSR flora. Leningrad, 1952; 18: 525-640.

13. Zuev, V.V., Gentianaceae of Siberia (evolution and phylogeny). Novosibirsk, 1991.

14. Ho, T.-N. and S.-W. Liu. A Worldwide Monograph of Gentiana. The Northwest Plateau Institute of Biology, the Chinese Academy of Science. Science Press, Beijing, New York, 2001.

15. Dzhalilova, Kh.Kh. Comparative karyology and taxonomy of the family Gentianaceae. In: Proceedings of $X$ Moscow council on plant phylogeny. Moscow, 1999; 69-71.

16. Davitashvili, N. and Karrer, G. Taxonomic importance of seed morphology in Gentiana (Gentianaceae). In: Botanical Journal of the Linnean Society. Austria, 2010; 101-115.

17. Sun Yang, Goncharov, A.A., Tsarenko, N.A., Tyan Yasing. On studying the morphology of the seeds of species of the genus Gentiana L. (Gentianaceae) growing in Primorskiy Territory. In: Bulletin of Krasnoyarsk State Agrarian University, 2015; 7: 158-163.

18. Barthlott, W. Epidermal and seed surface characters of plants: systematic applicability and some evolutionary aspects. Nord. J. Bot., 1981; 1: 345-354.

19. Artyushenko, Z.T. Atlas on descriptive 
morphology of higher plants. Seed. Leningrad, 1990.

20. Fedotova, T.A. The family Gentianaceae. In: Comparative anatomy of seeds. St. Petersburg,
2010; 7: 53-75.

21. Kravtsova, T.I. Comparative karyology of the family Urticaceae Juss. Moscow, 2009. 